${ }^{\circledR}$ Entomologica Fennica. 9.XII.1993

\title{
Hemiptera of Iraq. III. Heteroptera, Miridae (Phylinae)
}

\author{
Rauno E. Linnavuori
}

Linnavuori, R. E. 1993: Hemiptera of Iraq. III. Heteroptera, Miridae (Phylinae). — Entomol. Fennica 4:253-271.

An annotated list of the 76 species of the Miridae subfamily Phylinae known to occur in Iraq is presented. New synonymies: Chamaepsallus Wagner 1965 = Badezorus Distant 1910, Badezorus tyrianus Distant $1910=$ Atomoscelis signaticornis Reuter 1904, Maurodactylus pictus Wagner 1975 = Psallus deserticola Wagner 1951, Campylomma minima Wagner 1960 and C. verticata Wagner $1961=$ C. incerta Villiers 1956. New combinations: Chamaepsallus signaticornis (Reuter 1904) = Badezorus signaticornis (Reuter 1904), Chamaepsallus tomentosus $($ Reuter 1904) = Badezorus tomentosus $($ Reuter 1904).

Rauno E. Linnavuori, Somersoja, FIN-21220 Raisio 22, Finland

As pointed out in the preface to Part I of the Hemiptera of Iraq (Linnavuori 1992), only very few records (Hoberlandt 1949 and 1953) of the Miridae fauna of Iraq have been published. $\mathrm{Nu}-$ merous new species were described in Linnavuori 1984. A list containing 76 species of the subfamily Phylinae is published below. Since 98 species were listed in the previous part, the total number of the known Miridae species from Iraq is 174 . From the zoogeographical point of view a strong penetration of the Mediterranean element into the steppe and mountain regions of northern Iraq is noticeable. The fauna of the semidesert and desert zone resembles that of the adjacent parts of Saudi Arabia, although several species typical to the main parts of the Arabian deserts seem to be absent, undoubtedly owing to differences in the climatic and edaphic factors.

The collected material is the property of the American Museum of Natural History, but at present kept in the author's collection.

\section{Subfamily Phylinae}

\section{Tribe Hallodapini}

Acrorrhinium conspersus Noualhier, 1895

Material: Several exx from Dukan, 12.VI.1980; Salahuddin, 12.VI.1980; Sarsang, 26-28.VIII.1980, Linnavuori; Shaqlawa, 1 ex, Kalalova.

Biology: On bark of trunks and branches of large oaks. No connection with ants was observed.

Distribution: Syrio-Anatolian, recorded from Syria, Turkey, Bulgaria, and Iraq (Hoberlandt 1953:378).

Trichophorella splendida Linnavuori, 1984

Material: Baghdad, on holotype, many paratypes, IVVIII.1980; Ana, 1 paratype, 8.X.1979; Ain Al Tamar, 1 paratype, 17.VII.1980, Linnavuori, in coll. Linnavuori (AMNH). 
Biology: At lamps.

Distribution: Eremian, with Arabian distribution. Also known from Saudi Arabia.

\section{Hallodapus pseudoconcolor (Linnavuori, 1984), comb. n.}

Plagiorrhamma pseudoconcolor Linnavuori 1984:40.

Material: Sarsang, $O^{7}$ holotype, several paratypes, 2628.VIII.1980; several paratypes also from Baghdad, IVVI.1980 and Al Qosh, 25.VIII.1980, Linnavuori, in coll. Linnavuori (AMNH).

Biology: At lamps.

Distribution: Endemic.

\section{Hallodapus costai (Reuter, 1890)}

Material: Several exx from Ain Al Tamar, 17.VIII.1980; Ain Al Tamar-Karbala, 20.X.1979; Baghdad, IV-VII.1980; Dawra, 15.IX.1979, Linnavuori.

Biology: Under plants in fields and saline and sandy habitats. At lamps.

Distribution: Eremian, extending from the Cape Verde Islands to the Arabian Peninsula, Israel and Iraq.

\section{Hallodapus pilosus (Reuter, 1882)}

Material: Baghdad, 5 exx, IV-VIII.1980, Linnavuori.

Biology: At lamps.

Distribution: Holosudanese. Also known from Saudi Arabia.

\section{Laemocoris orphanus Linnavuori, 1964}

Material: Ain Al Tamar, 5 exx, 17.VII.1980, Linnavuori.

Redescription in Linnavuori 1984:39-40.

Biology: Under halophytic shrubs (Zygophyllum, Anabasis articulata) in a salt marsh. Living in colonies of a small red ant species, which in its body form and movements is misleadingly similar to females of $L$. orphanus.

Distribution: Eremian, with Arabian distribution. Also known from Saudi Arabia.

\section{Systellonotus thymi Signoret, 1859}

Material: Several exx from As Salman, 3.IV.1981; As Salman-Takhadid, 17.IV.1980, Linnavuori.
Biology: Together with ants under plants in sandy and gravelly habitats.

Distribution: Holomediterranean.

Alloeomimus kurdus Hoberlandt, 1953

Figs. 1a-h, 7a

Material: Aqra, 2 exx, 29.VIII.1980; Baghdad, 2 exx, IV-VI.1980; Baghdadi, 2 exx, 8.X.1979; Darbandikhan, 1 ex, 13.V.1980; Penjwin, 1 ex, 11.VI.1980; Qora, 1 ex, 13.VI.1980, Linnavuori.

Length $3.6-4.5 \mathrm{~mm}$. Very similar to $A$. unifasciatus (Reuter, 1879). Colour black (pale general colouring mentioned in the original description is apparently caused by immaturity; at least an immature specimen from Baghdadi is reddish brown). Head, pronotum, scutellum, apex of corium, and cuneus shinier than in A. unifasciatus. Basal part of pronotum more convex. Antennae more gracile, proportions between segments 10:29:26:18 ( $\left(^{7}\right), 10: 30: 26: 21(Q), 2$ nd joint $1.3\left(O^{1}\right), 1.25(Q) \times$ as long as basal width of pronotum. Ocular index about $1.71\left(\sigma^{7}\right)$ or $1.82($ (Q) (in unifasciatus about $2.0\left(\sigma^{7}\right), 2.53(0)$ ). Elytra in females about as long as abdomen, with distinct membrane (females of unifasciatus cryptobrachypterous with elytra much shorter than abdomen, membrane reduced).

Male genitalia in Fig. 1b-h, those of A. unifasciatus in Fig. 1i-k.

Biology: Among plants in hilly steppes. At lamps.

Distribution: Endemic (type locality: Shaqlawa).

\section{Alloeomimus pilosus Linnavuori, 1984}

Material: Penjwin, o holotype, Ơ paratype, 11.VI.1980, Linnavuori, in coll. Linnavuori (AMNH).

Biology: Among plants on dry precipice of a calcareous hill.

Distribution: Endemic.

\section{Glaphyrocoris ebikh Linnavuori, 1984}

Material: Sarsang, ơ holotype, 26-28.VIII.1980, Linnavuori, in coll. Linnavuori (AMNH).

Biology: At lamp in a deciduous mountain forest.

Distribution: Endemic. 


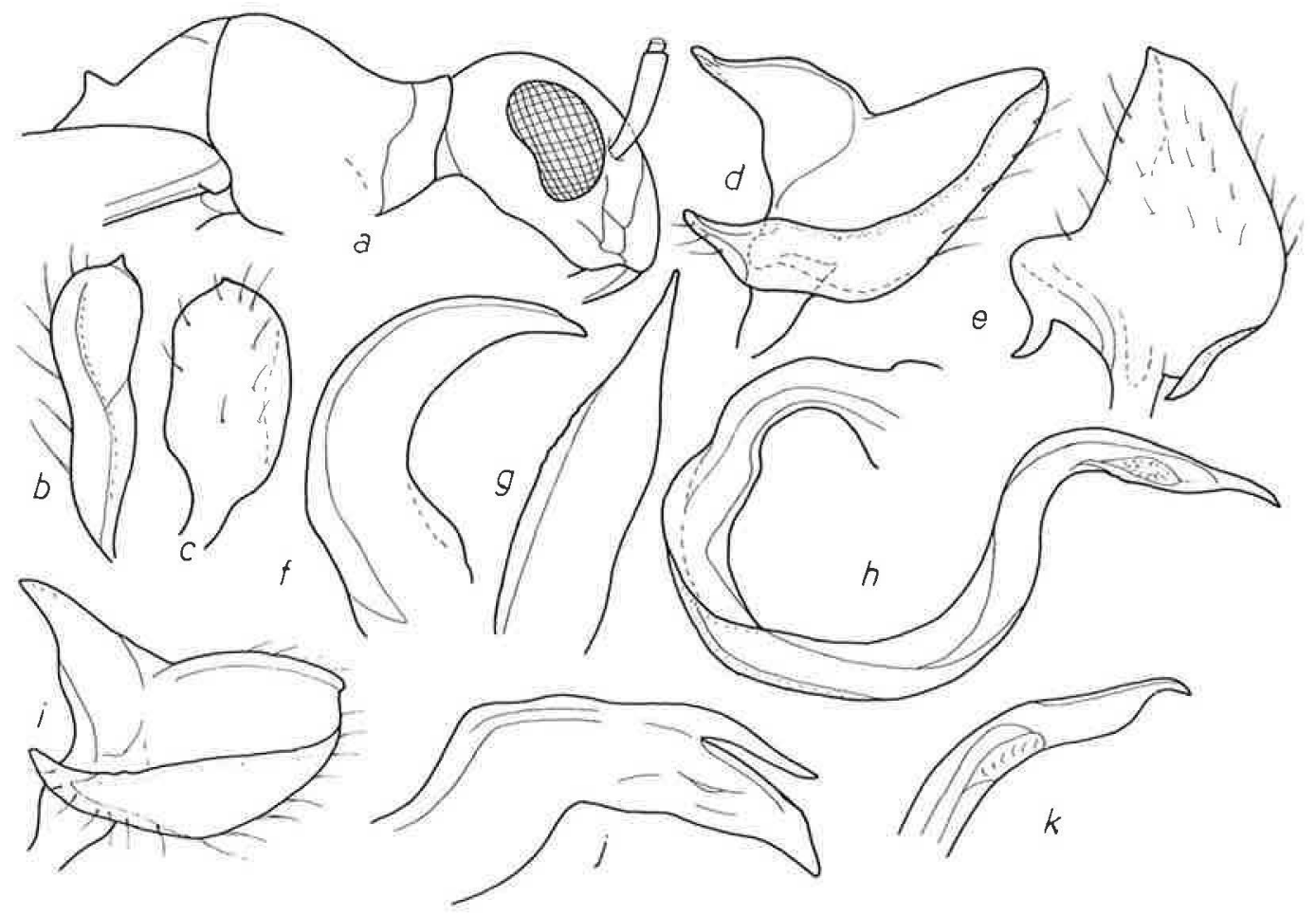

Fig. 1. Alloeomimus kurdus Hoberlandt. a: female head and thorax in lateral view; b-c: right style; d-e: left style; $\mathrm{f}-\mathrm{g}$ : theca in lateral and in dorsal view; h: vesica. - A. unifasciatus (Reuter) (ex from Tunisia, Oued Zeroud). i: left style; j: theca in lateral view; $k$ : apex of vesica.

\section{Tribe Phylini}

Nasocoris albipennis Lindberg, 1939

Fig. 2a-d

Material: Many exx from Abu Ghair, 15-16.IV.1980; Tharthar lake, 23.VIII.1979; Waqisah, 1.V.1980, Linnavuori.

Biology: On Ephedra alata in semideserts.

Distribution: Eremian, known from Egypt, Saudi Arabia and Israel.

\section{Nasocoris serratus Linnavuori, 1984}

Material: As Salman-Takhadid, $\sigma^{\top}$ holotype, several paratypes, 17-18.IV.1980, Linnavuori, in coll. Linnavuori (AMNH).

Biology: On Ephedra foliata in a little gravelly wadi.

Distribution: Endemic.
Macrotylus (Macrotylus) perdictus Kiritshenko, 1938

Material: Aqra, 8 exx, 12.V.1981; Kalak, 1 ex, 13.V.1981, Linnavuori.

Biology: On Echinops in hilly steppes of northern Iraq.

Distribution: Syrio-Anatolian, recorded from Cyprus, Israel, Syria, Turkey, Iran, and southern Russia.

Macrotylus (Alloeonycha) ancyranus Seidenstücker, 1969

Material: Gully Ali Beg, 2 exx, 13.VI.1980, Linnavuori.

Biology: In a hilly habitat. In Turkey found on Salvia.

Distribution: Anatolian, previously known from Turkey. 


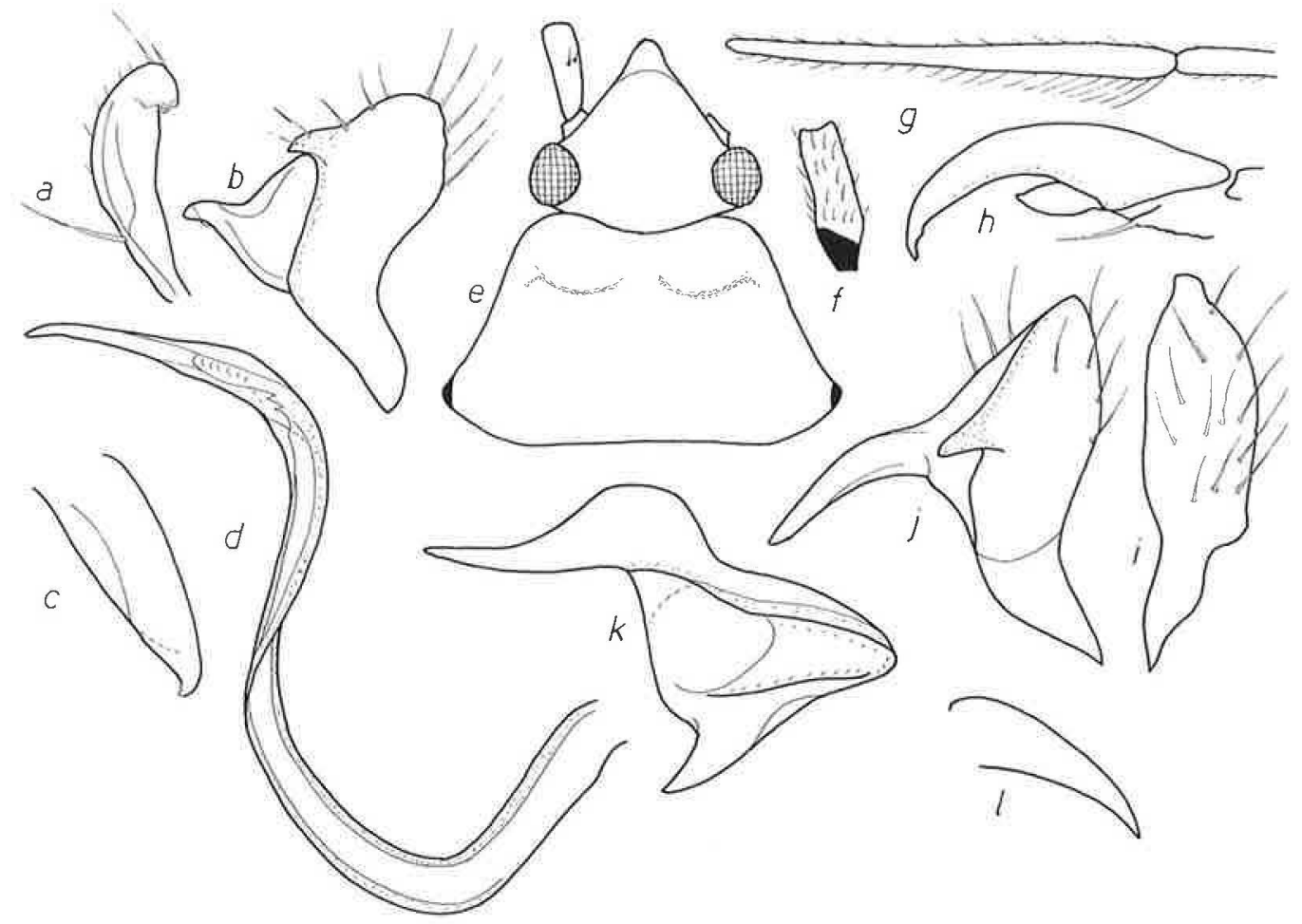

Fig. 2. Nasocoris albipennis Lindberg. a: right style; b: left style; c: theca; $d$ : vesica. - Oncotylus basicornis Horvath. e: female head and pronotum; f: 1st antennal joint; g: male 3rd antennal joint; h: claw; i: right style; j-k: left style from side and from above; l: theca.

Macrotylus (Alloeonycha) dahukanus Linnavuori, 1988

Material: Brozah, holotype male, a female paratype, 13.V.1981; Darbandikhan, 1 paratype, 13.V.1980, Linnavuori, in coll. Linnavuori (AMNH).

Biology: In mountain meadows.

Distribution: Endemic.

Oncotylus (Cylindromelus) setulosus (Herrich-Schäffer, 1837)

Material: Qora, 9 exx, 13.VI.1980, Linnavuori.

Biology: In a mountain meadow. On Centaurea (Wagner 1975a:249).

Distribution: Holomediterranean.
Oncotylus (Oncotylus) basicornis Horvath, 1901 Figs. 2e-1, 3a

Material: Shaykh Addy, 5 exx, 11.V.1981, Linnavuori.

Description in Wagner 1975a:253-254 is completed with the following data: Body $4.0\left(\mathrm{O}^{7}\right)$ or $3.2(q) \times$ as long as basal width of pronotum. Ocular index $2.1\left(O^{7}\right), 2.16-2.36(0)$. Proportions between antennal segments 11:47:33:17 $\left(\bigcirc^{7}\right)$, $12: 43: 28: 17(Q), 2$ nd joint $2.1\left(\sigma^{7}\right)$ or $1.72-1.83$ $(Q) \times$ as long as diatone, $1.31\left(O^{7}\right)$ or $1.02-1.16(q)$ $\times$ as long as basal width of pronotum; under surface of $3 \mathrm{rd}$ antennal segment in $\sigma^{7}$ with long hairs. Hind tibia about $2.45\left(\sigma^{\top}\right)$ or 1.8-2.2 (Q) $\times$ as long as basal width of pronotum.

Male genitalia in Figs. 2i-1, 3a.

Biology: In mountain meadows.

Distribution: Syrio-Anatolian; recorded from Syria (Akbes) and Turkey (Gaziantep). 


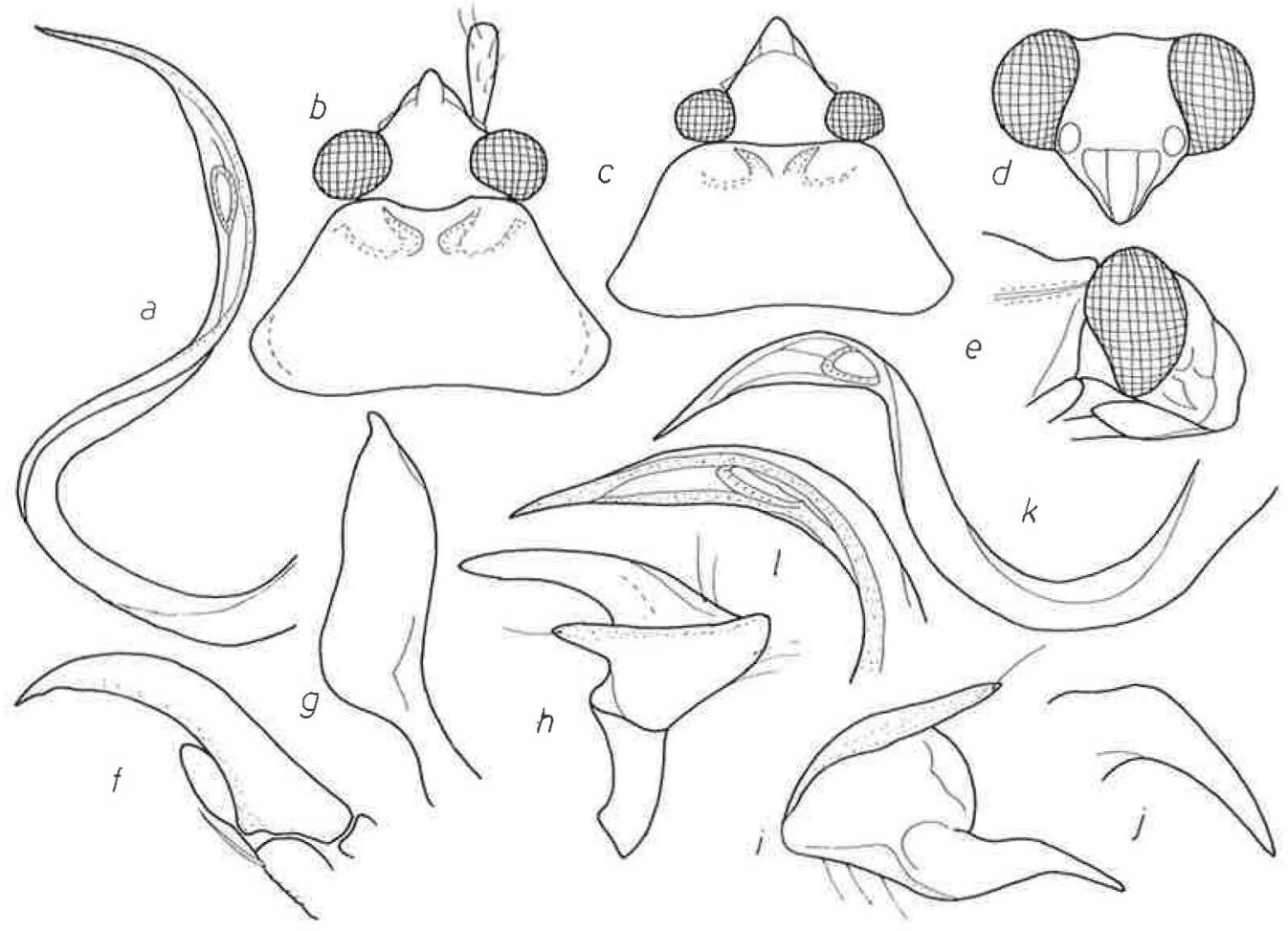

Fig. 3. Oncotylus basicornis Horvath. a: vesica. - Stenoparia putoni Fieber. b-c: male and female head and pronotum; d-e: male head in apical and in lateral view; f: claw; g: right style; h-i: left style from side and from above; j: theca; $\mathrm{k}$ : vesica; l: apex of vesica.

Oncotylus (Oncotylus) innotatus Wagner, 1970

Material: Many exx from Khorsabad, 11.V.1981 and Sinjar, 7.V.1981, Linnavuori.

Biology: In hilly steppes of northern Iraq. Swept from luxuriant vegetation consisting of grasses, Papilionaceae, Labiatae, and Compositae.

Distribution: Syrio-Anatolian, recorded from Syria, Israel and Turkey.

Stenoparia putoni Fieber, 1870

Fig. 3b-1

Material: Many exx from Al Hadr, 6-7.V.1981; A] Qosh, 10.V.1981; Rutba-Al Qaim, 4.V.1981; Sinoni, 89.V.1981; Safwan, 1 ex, 30.III.1981, Linnavuori. All specimens are dark-spotted (f. punctata Reuter, 1879).

Biology: In steppes. Recorded from Artemisia (Wagner 1975a:381).

Distribution: Holomediterranean.
Psallopsis basalis Reuter, 1904

Fig. 4a-e

Material: Iraq: Nasiriya-Abu Ghar, many exx, 15.IV. 1980, Linnavuori. Iran: Sisten, Shahr-i-Sokilta, 2 exx, 24.IX.1977, A. Vigna. Israel: Neot Hakikkar, many exx, 16-20.VII.1986, Linnavuori. Jordan: Suweima, numerous exx, 22.VII.1981, Linnavuori. Saudi Arabia (localities listed in Linnavuori 1986:177).

Biology: In salt marshes on halophytes such as Zygophyllum.

Distribution: Eremian, extending from Palestine to Iran.

Psallopsis bisulcis Linnavuori, 1961

Figs. 4f-i, 5a-d

Types: Palestine, $\sigma^{7}$ holotype in coll. Linnavuori (AMNH), ơ paratype in Mus. Helsinki, Bodenheimer.

Material: Iraq: Ana, 2 exx, 8.X.1979; Basra, 1 ex, 12.IV.1980; 50 km SE Nasiriya, 1 ex, 14.IV.1980; Nasiriya- 


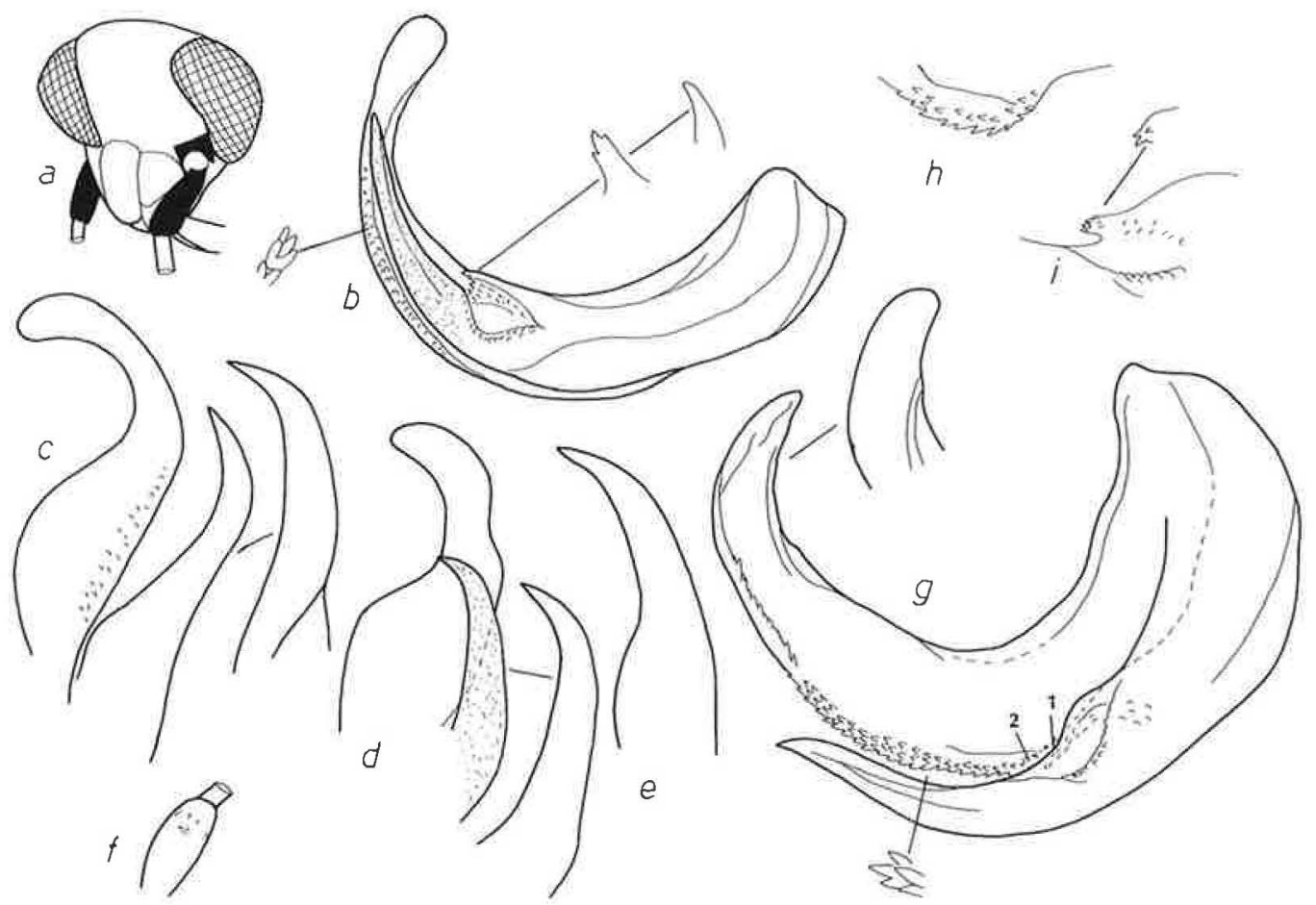

Fig. 4. Psallopsis basalis Reuter. a: head in anterolateral view; b: vesica (ex from Abu Ghar), lateral view; c-d: apex of vesica (exx from Abu Ghar and Al Hasa) in ventral view; e: lower sclerified process of vesica (ex from Suweima). - $P$. bisulcis Linnavuori. $\mathrm{f}$ : 1st antennal joint; $\mathrm{g}$ : vesica (ex from Tharthar lake) in lateral view; $\mathrm{h}-\mathrm{i}$ : processes marked with 1 and 2 in fig. $\mathrm{g}$.

Abu Ghar, 1 ex, 31.III.1981; Rutba-Al Qaim, 2 exx, 4.V.1980; Tharthar lake, 7 exx, 13.IX.1979, Linnavuori. Israel: many exx from Nahal Arugot, 22.VII.1986; Neot Hakikkar, 16-20.VII.1986, Linnavuori. Turkestan: Turkmenskaya SSR, Zahmjet, 3 exx, 24.IX.1975, Puchkov.

Wagner (1975a:388) regarded P. bisulcis as a pale form of $P$. basalis. Both taxa are, in fact, closely related, but nevertheless separate sister species. The main differences are:

1) P. bisulcis: Head and 1 st antennal segment uniformly pale, the latter at most with a few indistinct brownish spots. - P. basalis: 1 st antennal segment and a spot above antennal pits extending from base of clypeus to inner margin of eye blackish brown.

2) P. bisulcis: Lower sclerified process of vesica longer, straight, sharply needle-like. $-P$. basalis: Lower sclerified process of vesica shorter and thicker, apically curved. The up- per, weakly sclerified process of vesica is variable in shape, although it is often broader in $P$. basalis.

Both taxa are sympatric and occur even in same localities (Neot Hakikkar, Nasiriya-Abu Ghar). Since no intermediates are known, crossbreeding between them apparently does not occur.

Biology: In salt marshes on halophytes. At Thartar lake found on Aellenia subaphylla.

Distribution: Eremian, extending from Palestine to Turkestan.

\section{Psallopsis rufifemur Wagner, 1958}

Material: Many exx from Ain Al Tamar-Ramadi, 20.IV.1980; Basra, 12.IV.1980; Nasiriya-Abu Ghar, 15.IV and 29.VI.1980; Safwan, 30.III.1980; Sawa lake, 30.III. 1981, Linnavuori. 
Biology: In salt marshes on halophytes such as Arthocnemum glaucum, Salicornia herbacea and Seidlitzia rosmarina.

Distribution: Iranian, extending from Iraq and the adjacent parts of Saudi Arabia to Iran.

\section{Psallopsis similis Wagner, 1958}

Material: Iraq: Ana-Al Qaim, 1 ex, 5.V.1980; Baghdad, 1 ex, V-VI.1980; Al Hadr, 3 exx, 6-7.V.1981; RawahAl Hadr, 1 ex, 6.V.1981; Safwan, 6 exx, 30.III.1981; Sawa lake, 3 exx, 21.X.1979; Tharthar lake, 2 exx, 31.X.1979, Linnavuori. Syria: Deir es Zor, 1 ex, 11.VIII.1979, Linnavuori. Israel: 'Ein Avdat, 2 exx, 10.VIII.1986, Linnavuori.

Biology: In semideserts. At Tharthar lake found on Calligonum comosum.

Distribution: Eremian, extending from Palestine to Iran.

\section{Glaucopterum lycii Puchkov, 1975}

Claucopterum lycii Puchkov 1975:1040-1041.

Claucopterum lycii Linnavuori 1984: 43 (Kerzhner 1984: 46-47).

Types: Abu Ghar-Busaya, $\phi$ holotype and 20 paratypes of $G$. lycii Linnavuori, 1.IV.1981, Linnavuori, in coll. Linnavuori (AMNH).

Material: Turkestan: Turkmenskaya SSR, Kazandžikskii r.pos, Ahča-Kuima, $10^{\text {T }}$ and 2 ơ of $G$. lycii Puchkov, 7.V.1974, Puchkov, in coll. Linnavuori (AMNH).

$G$. lycii Linnavuori, a homonym of $G$. lycii Puchkov, was synonymized with the latter species by Kerzhner (1984:46-47). The examined females of $G$. lycii Puchkov differs from Iraqi specimens in larger eyes, ocular index 2.23-2.38 (in Iraqi specimens 2.50-2.53). Moreover, the 2nd antennal segment is somewhat shorter, 1.25$1.40 \times$ as long as diatone, $0.84-0.90 \times$ as long as the basal width of the pronotum (in Iraqi specimens $1.44-1.50 \times$ and $0.87-0.97 \times$ respectively). Unfortunately no males are known from Iraq for confirming the synonymy.

Biology: On Lycium barbarum.

Distribution: Apparently Irano-Turanian.

\section{Glaucopterum adspersum (Schmidt, 1939)}

Psallus adspersus Schmidt 1939:382.

Composidolon (Chamaeliops) adspersum Wagner 1975a: 148-149.

Material: Safwan, 1 ex, 30.III.1981, Linnavuori.
Biology: On Zygophyllum coccineum in sandy habitats.

Distribution: Eremian, extending from the Spanish Sahara and Tunisia to Iraq.

\section{Conostethus roseus (Fallén, 1829)}

Material: Several exx from Ash Sharqat, 7.IV.1980; Darbandikhan, 13.V.1980; Jebel Sinjar, 8.V.1981; Sinoni, 8-9.V.1981, Linnavuori.

Biology: Among grasses and other plants in hilly steppes of northern Iraq.

Distribution: Euro-Siberian.

Conostethus venustus (Fieber, 1859)

Material: Many exx from Aqra, 12.V.1981; Brozah, 17.V.1981; Darbandikhan, 13.V.1980; Al Hadr, 67.V.1981; Khorsabad, 11.V.1981; As Salman-Shabakah, 4.IV.1981; Ash Sharqat, 7.IV.1980, Linnavuori.

Biology: In steppes.

Distribution: Holomediterranean.

\section{Monocris longicornis Linnavuori, 1988}

Types: Nasiriyah-Abu Ghar, or holotype, numerous paratypes, 15.V.1980, Linnavuori, in coll. Linnavuori (AMNH),

Biology: On an unidentified halophyte in a salt marsh.

Distribution: Endemic.

\section{Malthacosoma punctipennis Reuter, 1879}

Malthacosoma halimocnemis (Becker, 1864) in Wagner 1975a:385-386, misidentification (Capsus halimocnemis Becker 1864:485 is a synonym of Solenoxyphus fuscovenosus Fieber, 1864, in Kerzhner \& Jaczewski 1964:752).

Material: Many exx from Amara, 18.VIII.1968, M. Kareem; Ana-Al Qaim, 5.V.1980; Baghdad, IV-VII.1980; Al Hadr, 6.V.1981; Haditha-Tikrit, 6.V.1980; NajafShabakah, 23.VI.1981; Rawah-A1 Hadr, 6.V.1981; Safwan, 30.III.1981, Linnavuori.

Colouring variable: Upper surface usually with fine or large dark dots, sometimes immaculate.

Biology: In steppes with grasses, Compositae and Astragalus. Between Haditha and Tikrit found on Halocharis sulphurea.

Distribution: Irano-Turanian, extending to Israel and Egypt. 
Atomophora arabica Linnavuori, 1962

Material: Najaf-Shabakah, 1 ex, 23.VI.1981; $50 \mathrm{~km} \mathrm{~S}$ Nasiriya, 1 ex, 14.IV.1980; Safwan, many exx, 13.IV.1980; Tharthar lake, 2 exx, 13.IX.1979; Ukhaydir-Nukhaib, 2 exx, 2.V.1980; Wadi Mandali, 1 ex, 29.IX.1979, Linnavuori.

Biology: At Tharthar lake found on Calligonum comosum. In Saudi Arabia common at lamps in Rhanterium epapposum steppes.

Distribution: Eremian (Arabian).

\section{Camptotylidea alhagii (Linnavuori, 1986)}

Atomophora alhagii Linnavuori 1986:155 (Linnavuori 1990:58-59).

Types: Iraq: near Ana, o holotype, several paratypes, 8.X.1979; Tharthar lake, 1 paratype, 23.VIII.1979, Linnavuori. Saudi Arabia: A1 Hasa, several paratypes, 24.X.1977, Linnavuori, in coll. Linnavuori (AMNH).

Biology: On Alhagi maurorum.

Distribution: Eremian (Arabian).

\section{Camptotylidea candida (Linnavuori, 1984)}

Atomophora candida Linnavuori 1984:40-41 (Linnavuori 1990:59).

Types: Ukhaidir-Nukhaib, $\mathrm{Q}$ holotype, 3 paratypes, 2.V. 1980; Nukhaib-km 160, several paratypes, 3.IV.1980, Linnavuori, in coll. Linnavuori (AMNH).

Biology: On Ephedra foliata.

Distribution: Endemic.

\section{Camptotylidea astarte (Linnavuori, 1971)}

Atomophora astarte Linnavuori 1971:3.

Taeniophorus grandoculus Linnavuori 1984:43 (Linnavuori 1990:60-61).

Types: Israel: Eilat, $\sigma^{r}$ holotype and 1 paratype of astarte, 10.V.1958, Linnavuori. Iraq: Nasiriyah-Abu Ghar, o' holotype and many paratypes of grandoculus, 15.IV.1980 and 31.III.1981, Linnavuori, in coll. Linnavuori (AMNH).

Biology: On Haloxylon persicum.

Distribution: Irano-Turanian, extending from Israel and Saudi Arabia to Turkestan.

Camptotylidea fuscomaculata (Reuter, 1879)

Atomophora fuscomaculata Reuter 1879:291 (Linnavuori 1990:62).

Material: Ukhaydir-Nukhaib, 4 exx, 2.V.1980, Linnavuori.
Biology: On Haloxylon persicum.

Distribution: Irano-Turanian, extending from Saudi Arabia and Iraq to Central Asia.

Roudairea crassicornis Reuter, 1886

Material: Safwan, many exx, 13.IV.1980, Linnavuori.

Biology: On Panicum turgidum in sandy habitats.

Distribution: Eremian (Algeria - Iraq).

Opisthotaenia fulvipes Reuter, 1901

Material: Al Qosh, 3 exx, 10.V.1981, Linnavuori.

Biology: In hilly steppes. On Boraginaceae.

Distribution: Pontomediterranean.

Thermocoris rivalis (Horvath, 1894)

Material: Aqra, 6 exx, 12.V.1981; Brozah, 1 ex, 13.V.1981, Linnavuori.

T. rivalis consists of two known races, $T$. rivalis rivalis occurring in Armenia and $T$. rivalis suctor Seidenstücker inhabiting Turkey. They differ in the length of the rostrum which in the former extends to the basal margin of the mesonotum, in the latter much beyond the hind coxae. The Iraqi specimens seem to be intermediates, since the rostrum extends to the hind coxae or slightly beyond.

Biology: In hilly steppes of northern Iraq. Recorded from Alkanna in Turkey (Wagner 1975a:360).

Distribution: Anatolian.

Tinicephalus vicarius Linnavuori, 1984

Types: near Brozah, ơ holotype, 2 o paratypes, 13.V. 1981, Linnavuori, in coll. Linnavuori (AMNH).

Biology: In steppes on hilly terrain. Vegetation consisting of different grasses, Papilionaceae and Labiatae.

Distribution: Endemic.

Amblytylus macedonicus Wagner, 1956

Material: Brozah, 4 exx, 13.V.1981; Al Hadr, 4 exx, 6-7.V.1981, Linnavuori.

Biology: On grasses in steppes of northern Iraq. 
Distribution: Pontomediterranean, known from Slovakia, the Balkan Peninsula and Turkey.

\section{Amblytylus gregarius Linnavuori, 1961}

Material: Several exx from Aqra, 12.V.1981; Brozah, 13.V.1981; Darbandikhan, 13.V.1980; Al Qosh, 10.V.198I; Shaykh Addi, 11.V.1981, Linnavuori.

Biology: On grasses in hilly steppes of northern Iraq.

Distribution: Apparently Syrio-Anatolian, previously recorded from Israel.

\section{Amblytylus concolor Jakovlev, 1877}

Material: Numerous exx from Agra, 12.V.1981; Brozah, 13.V.1981; Darbandikhan, 13.V.1980; Al Hadr, 6-7.V.1981; Jebel Sinjar, 8.V.1981; AI Qosh, 10.V.1981; Shaykh Addi, 11.V.1981; Sinjar, 7.V.1981; Sinoni, 89.V.1981, Linnavuori.

Biology: On grasses in hilly steppes of northern Iraq.

Distribution: Pontomediterranean.

Amblytylus luridus Hoberlandt, 1961

Material: Several exx from Aqra, 12.V.1981; Brozah, 13.V.1981; Darbandikhan, 13.V.1980; Sinjar, 7.V.1981, Linnavuori.

Biology: On grasses in hilly steppes of northern Iraq.

Distribution: Syrio-Anatolian.

\section{Tytthus parviceps (Reuter, 1890)}

Material: Amara, 1 ex, 23-24.X.1979; Ana, 1 ex, 8.X. 1979; Baghdad, 4 exx, V-VII.1980; Jalula, I ex, 27.XI. 1979; Mosul, 2 exx, 28.VIII.1980; Sawa lake, 1 ex, 21.X. 1979, Linnavuori.

Biology: On Cyperaceae and grasses in moist localities.

Distribution: Intertropical.

\section{Ectagela guttata Schmidt, 1939}

Material: Numerous exx from Ain Al Tamar, 17.V. 1980; Ana, 8.X.1979; Abu Ghar-Busaya, 1.IV.1981; Baghdad, IV-VIII.1980; Busaya-As Salman, 2.IV.1981; Nasiriya, 22.X.1979, Linnavuori.
Biology: On Zizyphus spina-christi. At lamps. Distribution: Eremian; known from Egypt.

Ectagela aspera Linnavuori, 1984

Types: Sarsang, or holotype, $Q$ paratype, 26-28.VIII. 1980, Linnavuori, in coll. Linnavuori (AMNH).

Biology: At lamp on a mountain slope. Vegetation containing oaks, grasses and Compositae.

Distribution: Endemic.

Yotvata (Yotvata) picticornis (Horvath, 1913)

Material: Najaf-Shabakah, 10 exx, 23.VI.1981, Linnavuori.

Biology: On Acacia.

Distribution: Eremian (Algeria-Iraq).

\section{Yotvata (Yotvata) nergal Linnavuori, 1984}

Type: Baghdad, ơ holotype, IV-V.1980, Linnavuori, in coll. Linnavuori (AMNH).

Biology: At lamp.

Distribution: Endemic.

Yotvata (Godataira) salmana Linnavuori, 1984

Types: As Salman-Takhadid, $O^{\top}$ holotype, $\bigcirc$ paratype, 17.IV.1980, Linnavuori, in coll. Linnavuori (AMNH).

Biology: Swept from vegetation in a small gravelly wadi.

Distribution: Endemic.

Yotvata (Godataira) pulcherrima Linnavuori, 1984

Types: near Dukan, ơ holotype, several paratypes, 12.VI.1980; Salahuddin, I paratype, 12.VI.1980; Sarsang, 1 paratype, 26-28.VIII.1980, Linnavuori, in coll. Linnavuori (AMNH).

Material: Aqra, 3 exx, 29.VIII.1980, Linnavuori.

Biology: On Quercus aegilops. At Aqra on Vitex agnus-castus.

Distribution: Endemic.

\section{Compsidolon (Compsidolon) elegantulum} Reuter, 1900

Material: Many exx from Gully Ali Beg, 13.VI.1980; Jebel Sinjar, 14.XI.1979; Al Qosh, 17.XI.1979; Sarsang, 26-28.VIII.1980, Linnavuori. 
Biology: On Parietaria on steep mountain precipices.

Distribution: Syrian, previously known from Syria, Israel and Jordan.

\section{Compsidolon (Coniortodes) alibeganum}

Linnavuori, 1984

Types: Gully Ali Beg, ơ holotype, 2 o paratypes, 13.VI.1980, Limnavuori, in coll. Linnavuori (AMNH).

Biology: In a luxuriant deciduous forest on precipices of a mountain river valley.

Distribution: Endemic.

\section{Compsidolon (Coniortodes) ishmedagan} Linnavuori, 1984

Types: near Salahuddin, ơ holotype, many paratypes, 12-14.VI.1980, Linnavuori, in coll. Linnavuori (AMNH).

Biology: On an unidentified Labiatae on slopes of a calcareous hill.

Distribution: Endemic.

\section{Compsidolon (Apsinthophylus) bipunctatum} Wagner, 1975

Material: Rutba-Al Qaim, many exx, 4-5.V.1980, Linnavuori.

Biology: On Artemisia herba-alba. Syria.

Distribution: Syrian, previously known from

\section{Composidolon (Apsinthophylus) sabulicola} Linnavuori, 1984

Types: Ukhaidir-Nukhaib, ơ holotype, many paratypes, 2.V.1980, 7.IV.1981, Linnavuori, in coll. Linnavuori (AMNH).

Biology: On Artemisia monosperma in inland dunes.

Distribution: Eremian (Arabian), also known from Saudi Arabia.

\section{Compsidolon (Apsinthophylus) balachowskii Wagner, 1958}

Material: Numerous exx from Abu Ghar-Busaya, 1.IV.1981; Rutba-Al Qaim, 4-5.V.1980; As Salman, 18.IV.1980; As Salman-Samawa, 16.IV.1980; As Salman-
Shabakah, 4.IV.1981; As Salman-Takhadid, 16.VIII.1980; Shabakah-Waqisah, 5.IV.1981, Linnavuori.

Biology: On Artemisia herba-alba.

Distribution: Eremian, extending from North Africa to Iraq.

Compsidolon (Apsinthophylus) qoshanum Linnavuori, 1984

Types: Al Qosh, o' holotype, 5 paratypes, 17.XI.1979, Linnavuori, in coll. Linnavuori (AMNH).

Biology: From herbs on precipices of a mountain valley.

Distribution: Endemic.

Psallus (Apocremnus) syriacus Wagner, 1956

Psallus (Apocremnus) ancorifer syriacus Wagner 1956b: 206-207.

Psallus (Apocremnus) syriacus Kerzhner \& Jaczewski 1964:756.

Material: Several exx from Aqra, 12.V.1981; Brozah, 13.V.1981; Darbandikhan, 13.V.1980; Gully Ali Beg, 2 우, 13.VI.1980, Linnavuori.

Biology: In hilly steppes of northern Iraq. In Crimea found on Alyssum.

Distribution: Syrio-Anatolian, recorded from Israel, Syria, Turkey, and Crimea.

\section{Psallus (Psallus) pseudopunctulatus}

Linnavuori, 1984

Types: Jebel Sinjar, $0^{\top}$ holotype, many paratypes, 8.V. 1981; near Salahuddin, 1 paratype, 16.VI.1980, Linnavuori, in coll. Linnavuori (AMNH).

\section{Biology: On Quercus.}

Distribution: Endemic.

Psallus (Psallus) deserticola Wagner, 1951

Figs. 5e-d, 6a-c, 7b-h

Maurodactylus pictus Wagner 1975c:274-276, syn. n.

Types: Syria: $40 \mathrm{~km}$ SW Deir Es Zor, 3 paratypes of pictus, 15.V.1974, Eckerlein, in coll. Linnavuori (AMNH).

Material: Iraq: Rawah-Al Hadr, 9 exx, 6.V.1981, Linnavuori. Israel: Many exx from 'Ein Avdat, 10.VIII.1986; Hazerim, 30.IV.1986; Revivim, 21.IV.1986, Linnavuori. Egypt: Cairo-Suez desert road, numerous exx, 14-15.IX. 1962, Linnavuori; Wadi Umm Assad, 2 exx (topotypic), 14.X.1934, Priesner. 

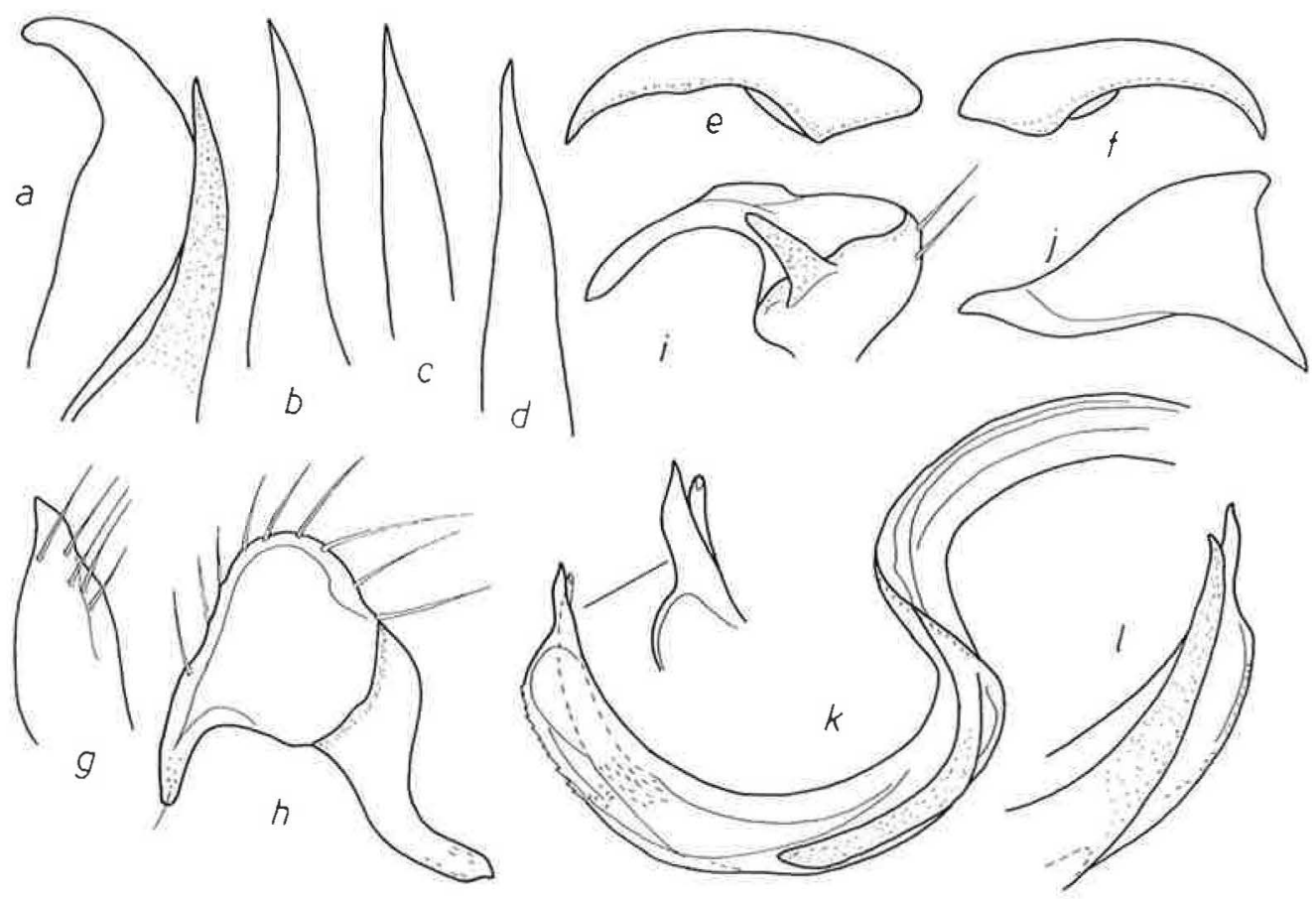

Fig. 5. Psallopsis bisulcis Linnavuori. a: apex of vesica (ex from Turkestan) in ventral view; b-d: lower sclerified process of vesica (ex from Nasiriya and of two exx from Tharthar lake). - Psallus deserticola Wagner. e-f: claw (exx from Egypt and Rawah-Al Hadr); g: right style; h-i: left style from above and in lateral view; j: theca; k-l: vesica (ex from Rawah-Al Hadr) in lateral view.

Description: Length 3.25-4.0 $\mathrm{mm}$. Color variable. Ground color pale grayish or orangish. 1 st antennal joint black, others yellowish. Males: In darkest specimens head, pronotum and scutellum blackish brown, clavus with obscure brown spot, apex of corium with transverse dark band, apical part of cuneus brownish. In pale specimens head, pronotum and scutellum yellowish, transverse band on apex of corium brownish, cuneus uniformly pale. Females: Dark specimens: head yellowish with reddish lateral arcs; pronotum and scutellum dark brown, elytra with dark spot extending from clavus to adjacent part of corium, broad blackish band across apex of corium, cuneus apically darkened. Pale specimens: head, pronotum and scutellum pale, dark band across apex of corium, apex of cuneus slightly darkened. All forms are connected with intermediates. Legs pale ochraceous. Femora with brown irroration, hind femora \pm darkened, sometimes even blackish brown. Tibiae with small dark spots which diminish in size towards the apex, tibial spines pale brown. - Vestiture: Upper surface with semierect pale hairs and dense appressed whitish yellow pubescence which is often worn out. 3rd hind tarsomere a little longer than 2 nd. Other external characters in the original descriptions and illustrations (Figs. 5e-f, 7bh). - Male genitalia in Figs. 5g-1, 6a-c. Vesica incrassate, apical part broadly curved, subapically finely dentate, apex bifid; gonopore subapical, poorly delimited.

Wagner (1975c:274-276) placed the species (as pictus) in the genus Maurodactylus Reuter, 


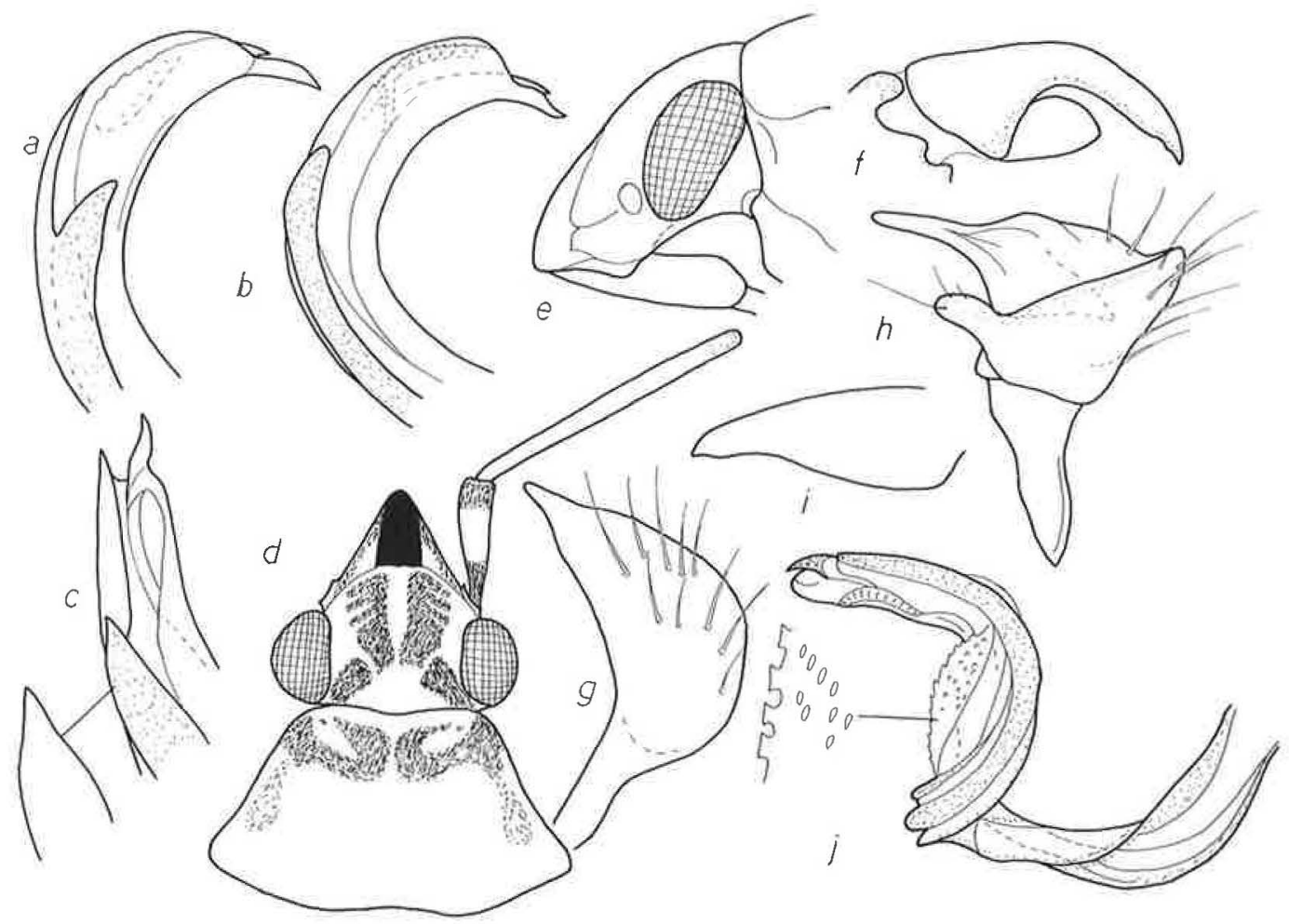

Fig. 6. Psallus deserticola Wagner. a-b: apex of vesica (exx from Rawah-Al Hadr and Egypt), lateral view; c: apex of vesica (ex from Egypt) in ventral view. - Chlorillus pictoides Wagner. d: male head and pronotum in dorsal view; e: head in lateral view; f: claw; g: right style; h: left style; i: theca; j: vesica in lateral view.

1878 (type species: Phytocoris albidus Kolenati) of which the following species preserved in coll. Linnavuori were examined: $M$. acanthophytii Puchkov, M. albidus (Kolenati), M. alutaceus (Fieber), M. fulvus (Reuter), M. gomerensis Wagner, M. kukuensis Puchkov, and M. nigrigenis (Reuter). These differ from $P$. deserticola in the following points:

1) Body smaller and in males especially, much more gracile, elongate and parallel-sided.

2) Elytra always uniformly pale.

3) Tibial spines long and black; tibiae immaculate save for very small dark dots at base of spines (most distinct in acanthophytii and kukuensis).

4) Hair covering of upper surface simple pale or black (acanthophytii and kukuensis), only in
M. kukuensis appressed silvery hairs also present.

5) Structure of vesica different.

Consequently deserticola does not seem to be congeneric with the Maurodactylus species and is therefore left in the crowded genus Psallus Fieber, where it does have a separate position, as pointed out by Wagner (1951:159-161).

Wagner (1975c:274-276) also suggested that the species could belong to the genus Damioscea Reuter, 1883 (type species: Oncotylus komaroffi Jakovlev), but that genus does not belong to the Maurodactylus group, from which it differs in several basic characters: 1. Legs much longer and more gracile. 3rd hind tarsomere shorter than 2nd. Pulvilli (Fig. 8e) large, extending to near apical third of claw. 4. Structure of vesica dis- 


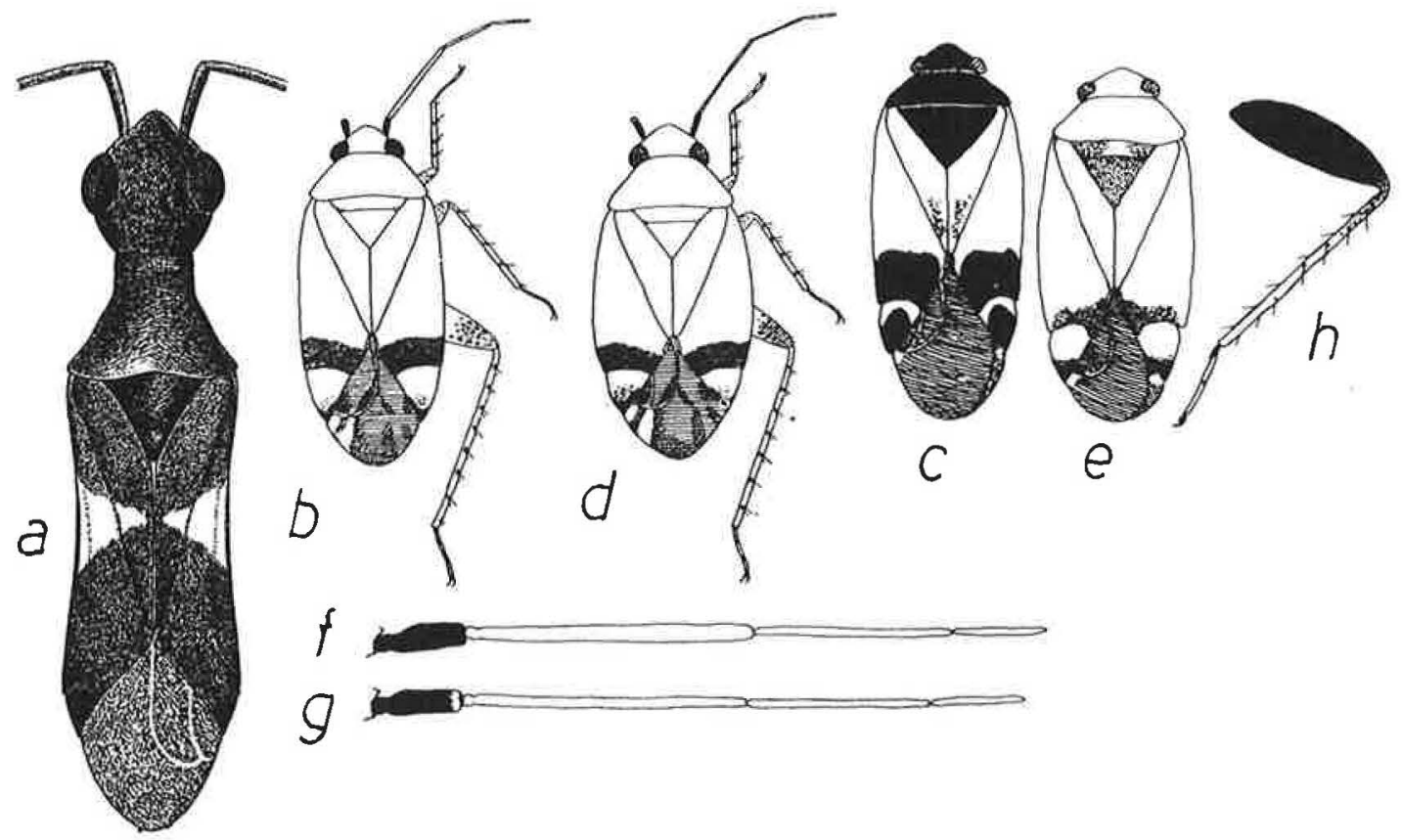

Fig. 7. Alloeomimus kurdus Hoberlandt. a: male in dorsal view. - Psallus deserticola Wagner. b-c: pale and dark male; d-e: pale and dark female; f-g: male and female antenna; $h$ : hind leg of a dark specimen. - After Hoberlandt 1953 and Wagner 1951 and 1975c.

similar (Fig. 8j). Damioscea is undoubtedly a member of the Megalocoleus group in which it was correctly placed by Kerzhner and Jaczewski (1964:754). A redescription of $D$. komaroffi is published below.

\section{D. komaroffi (Jakovlev, 1881)}

Fig. 8

Type: Russia: Dagestan, o' syntype, in coll. Reuter in Mus. Helsinki.

Description: Length 4.5-4.8 mm. Shiny. Pale yellowish green. Head yellowish. Eyes dark brown. 1 st and 2 nd antennal joints (others missing) dark brown. Membrane of elytra hyaline, immaculate. - Male: Body elongate, parallelsided. Hair covering of upper surface simple, dark. Head $0.68 \times$ as broad as basal width of pronotum, in apical view $1.3 \times$ as broad as high, in lateral view $1.14 \times$ as long as high; antennal pits close to lower corners of eyes; base of vertex immarginate; ocular index 1.15. Antennal joints 1 and 2 incrassate, hair covering semierect, 1 st joint $0.33 \times$ as long as diatone, 2 nd $1.54 \times$ as long as diatone, $1.04 \times$ as long as basal width of pronotum. Rostrum extending to base of abdomen. Pronotum trapezoidal, strongly broadening caudad, $2.1 \times$ as broad as long in middle, lateral margins straight, disc weakly convex. Elytra much longer than abdomen. Legs long and gracile; hind tibia $1.9 \times$ as long as basal width of pronotum, tibial spines black, longer than tibial diameter; proportions between hind tarsomeres 12:26:19.

Male genitalia in Fig. 8f-j.

Distribution: Caspian.

Psallus (Asthenarius) melpomene Linnavuori, 1989

Asthenarius melpomene Linnavuori 1989:53.

Type: Jebel Sinjar, $q$ holotype, 8.V.1981, Linnavuori, in coll. Linnavuori (AMNH). 


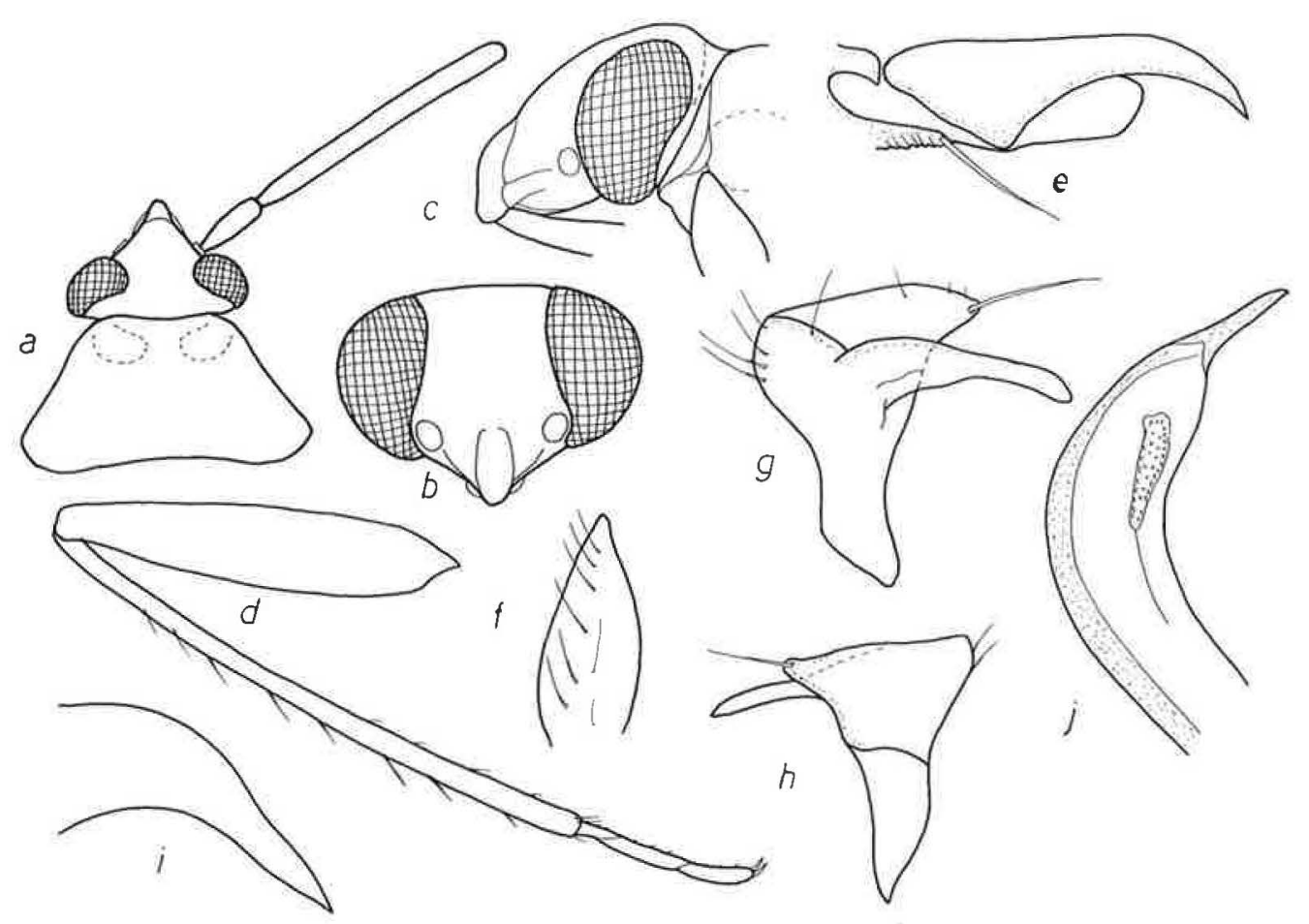

Fig. 8. Damioscea komaroffi (Jakovlev). a: head and pronotum; b-c: head in apical and in lateral view; d: hind leg; e: claw; f: right style; $\mathrm{g}-\mathrm{h}$ : left style; i: theca; j: apex of vesica.

Biology: On Quercus.

Distribution: Endemic.

Psallus (Asthenarius) ninurta Linnavuori 1984

Asthenarius ninurta Linnavuori 1984:50-51.

Type: near Dukan, ơ holotype, 12.VI.1980, Linnavuori, in coll. Linnavuori (AMNH).

Biology: On Quercus aegilops.

Distribution: Endemic.

\section{Nanopsallus carduellus (Horvath, 1888)}

Material: Several exx from Jebel Sinjar, 8.V.1981; Salahuddin, 12.VI.1980; Sarsang, 26-28.VIII.1980; Sawarah Tuka, 28.VIII.1981, Linnavuori.

Biology: On Cirsium acarna in hilly habitats.

Distribution: Pontomediterranean.
Chlorillus pictoides Wagner, 1964 Fig. 6d-j

Material: Jebel Sinjar near Sinoni, 8.V.1981, 2 exx; A1 Qosh, 6 exx, 10.V.1981, Linnavuori.

Biology: In hilly steppes of northern Iraq. In Syria found on Salvia acetabulosa (Wagner 1975a:10).

Distribution: Syrian, recorded only from Syria.

Pararagmus annulicornis (Reuter, 1879)

Recorded from Badawa, Erbil (Hoberlandt 1949:9).

Distribution: Irano-Turanian. 
Plagiognathus (Plagiognathus) bipunctatus Reuter, 1883

Material: Numerous exx from Aqra, 12.V.1981; Baghdad, IV-V.1980; Brozah, 13.V.1981; Darbandikhan, 13.V.1980; Gully Ali Beg, 13.VI.1980; Al Hadr-Sinjar, 7.V.1981; Halabja, 11.VI.1980; Jebel Sinjar, 8.V.1981; Khorsabad, 11.V.1981; Al Qosh, 10.V.1981; Safwan, 13.IV.1980; Sinjar, 7.V.1981; Sinoni, 8-9.V.1981, Linnavuori.

Biology: In steppes. Also found on Mentha in moist localities.

\section{Plagiognathus (Plagiognathus) chrysanthemi (Wolff, 1864)}

Material: Aqra, 1 ex, 12.V.1981; Darbandikhan, several exx, 13.V.1980, Linnavuori.

Biology: In steppes.

Distribution: Holarctic.

\section{Plagiognathus (Plagiognathus) fulvipennis} (Kirschbaum, 1856)

Material: Many exx from Abu Ghraib, 12.IV.1977, Waiel; Brozah, 13.V.1981; Darbandikhan, 13.V.1980; Dukan, 12.VI.1980; Gully Ali Beg, 13.VI.1980; Salahuddin, 13-14.VI.1980, Linnavuori.

Biology: In hilly steppes of northern Iraq.

Distribution: Holomediterranean.

\section{Genus Badezorus Distant}

Badezorus Distant 1910:15. Type species: B. tyrianus Distant.

Chamaepsallus Wagner 1965:85-86. Type species: Atomoscelis tomentosus Reuter, syn. n.

The synonymy was established after examining the type specimens of Badezorus tyrianus Distant in the British Museum.

Badezorus signaticornis (Reuter, 1904), comb. n.

Atomoscelis signaticornis Reuter 1904:20.

Chamaepsallus signaticornis Wagner 1965:86.

Badezorus tyrianus Distant 1910:283, syn. n.

Types: Pakistan, Lahore, Punjab, o lectotype (designated by Schuh) of tyrianus, $0^{7}$ syntype, 9.V.1908, N.A., in the British Museum.

Material: Many exx from Ain Al Tamar, 17.VI.1980; Ana, 8.X.1979; Baghdad, IV-VIII.1980; Haditha, 13.VIII. 1979; Mosul, 28.VIII.1980; Najaf-Shabakah, 1.V.1980;
Nasiriya-Abu Ghar, 29.VI.1980; Al Qosh, 25.VIII.1980; Rutba-Al Qaim, 4.V.1980; As Salman, 18.IV.1980; As Salman-Shabakah, 4.IV.1981; As Salman-Samawa, 16.IV. 1980; Sinjar, 7.V.1980; Waqisah, 1.V.1980, Linnavuori.

Biology: On herbaceous desert plants such as Aerva javanica, Arnebia hispidissima and $\mathrm{He}$ liotropium.

Distribution: Eremian, extending from the Cape Verde Islands to Iran and Pakistan.

Badezorus tomentosus (Reuter, 1904), comb. n.

Atomoscelis tomentosus Reuter 1904:21.

Chamaepsallus tomentosus Wagner 1965:74-92.

Material: Many exx from Ana, 8.X.1974; Baghdad, IV-VIII.1980; Al Hadr, 6-7.V.198I; Najaf-Shabakah, 1.V.1980, 23.VI.1981; $50 \mathrm{~km} \mathrm{~S} \mathrm{Nasiriyah,} \mathrm{14.IV.1980;}$ Nukhayb-km 160, 8.IV.1981; Safwan, 25.VI.1980; As Salman, 18.IV.1980; As Salman-Takhadid, 18.IV.1980; Az Zubayr, 14.IV.1980, Linnavuori.

Biology: In desert habitats on Heliotropium.

Distribution: Eremian, extending from Egypt to Iraq.

\section{Atomoscelis onustus (Fieber, 1861)}

Material: Numerous exx from Ain Al Tamar-Ramadi, 20.IV.1980; Ana, 10.IV.1981; Ana-Al Qaim, 5.V.1980; Baghdad, V-VII.1980; Najaf-Shabakah, 23.VI.1981; Sawa lake, 9.IV.1980; Sinjar, 7.V.1981, Linnavuori.

Biology: On Atriplex halimus is saline habitats.

Distribution: Holomediterranean.

\section{Salicarius urnammu Linnavuori, 1984}

Types: Halabja, O $^{2}$ holotype, 10 paratypes, 11.VI.1980, Linnavuori, in coll. Linnavuori (AMNH).

Biology: On Salix sp.

Distribution: Endemic.

\section{Sthenaropsis convolvuli Linnavuori, 1984}

Types: near Safwan, $0^{7}$ holotype, numerous paratypes, 13.IV.1980 and 30.III.1981; several paratypes from Abu Ghar, 16.IV.1980, and Az Zubayr, 14.IV.1980, Linnavuori, in coll. Linnavuori (AMNH).

Biology: On Convolvulus oxyphyllus.

Distribution: Eremian (Arabian), also known from Saudi Arabia. 
Maurodactylus nigrigenis (Reuter, 1890)

Campylognathus nigrigenis Reuter 1890:258.

Maurodactylus orientalis Wagner 1961a:309-313 (Linnavuori 1986:177).

Material: Several exx from Basra, 13.IV.1980; AnaAl Qaim, 5.V.1980; Al Hadr, 6.V.1981; Safwan, 13.IV. 1980, 30.III.1981; Waqisah, 1.V.1980, Linnavuori.

Biology: On desert plants and shrubs such as Calligonum comosum, Fagonia indica, Francoeuria crispa, and Artemisia herba-alba.

Distribution: Eremian, extending from North Africa to Central Asia.

\section{Campylomma diversicornis Reuter, 1878}

Material: Numerous exx from Abu Ghar-Busaya, 1.IV.1981; Ain Al Tamar, 17.VII.1980; Amara, 23-24. X.1979; Ana, 5.X.1979; Ana-Al Qaim, 5.V.1980; Aqra, 29.VIII.1980; Baghdad, V-VI.1980; Busaya, 2.IV.1981; Busaya-As Salman, 2.IV.1981; Falluja, 5.X.1979; Al Hadr, 6-7.V.1981; Jebel Sinjar, 8.V.1981; Karbala-Ain Al Tamar, 20.X.1979; Khan Ruhabah, 6.IV and 24.VI.1981; Khorsabad, 10.V.1981; Mosul, 28.VIII.1980; NajafShabakah, 1.V.1980; Nukhayb-km 160, 8.IV.1981; Al Qosh, 10.V.1981; Safwan, 13.IV.1979; As Salman, 3.IV.1981; As Salman-Shabakah, 16.IV.1981; Sarsang, 2528.VIII.1980; Sawa lake, 20.X.1979; Shaykh Addi, 11.V.1981; Sinjar, 14.XI.1979; Sinoni, 8-9.V.1981; Tharthar lake, 23.VIII.1979; Ukhaydir-Nukhayb, 2.V.1980; Wadi Mandali, 29.IX.1979; Az Zubayr, 14.IV.1980, Linnavuori; Bishapur, 1.IX.1930 and Belek Sindjar, VIII. 1931 (Hoberlandt 1949:9).

Biology: One of the commonest mirid species in Iraq. In semideserts and steppes on plants such as Artemisia herba-alba, thistles and Vitex agnuscastus.

Distribution: Irano-Turanian.

Campylomma simillima Jakovlev, 1882

Recorded from Shaqlawa (Hoberlandt 1953: 379).

Distribution: Irano-Turanian.

\section{Campylomma annulicornis (Signoret, 1865)}

Material: Halabja, 5 exx, 11.VI. 1980, Limnavuori.

Biology: On Salix sp.

Distribution: Holomediterranean.
Campylomma incerta Villiers, 1956

Campylomma minima Wagner 1960:94-96, syn. n. Campylomma verticata Wagner 1961b:320-322, syn. n.

Type: Mauritania, Chinquette, $0^{\top}$ holotype of incerta, 4 5.III.1951, Dekeyser \& Villiers, in Mus. Paris.

Material: Iraq: Abu Ghar, 1 ex, 16.IV.1980; Ain Al Tamar-Ramadi, 1 ex, 20.IV.1980; Najaf-Shabakah, 1 ex, 23.VI.1981; Rutba-Al Qaim, 2 exx, 5.IV.1981; As SalmanTakhadid, 1 ex, 17.IV.1980; Waqisah, 1 ex, 1.V.1980, Linnavuori. Kuwait: Al Jahra, 1 ex, 17.III.1981; As Salimiyah, 1 ex, 15-16.III.1981, Linnavuori.

Biology: On desert plants and shrubs such as Dipterygium glaucum, Lycium and Zizyphus.

Distribution: Eremian, extending from North Africa to Iraq.

\section{Campylomma unicolor Poppius, 1914}

Campylomma impicta Wagner 1956:7-9 (Linnavuori 1986:163).

Material: Many exx from Ain Al Tamar, 17.VII.1980; Baghdad, IV-VIII.1980; Falluja, 5.X.1979; Khan Ruhabah, 24.VI.1981; Najaf-Shabakah, 23.VI.1981; Sawa lake, 21.X.1979, Linnavuori.

Biology: In fields and desert habitats. On cultivated plants and natural vegetation such as Acacia, Zizyphus, Artemisia herba-alba, and Suaeda pruinosa.

Distribution: Holosudanese with a wide range in the Eremian subregion.

Campylomma lindbergi Hoberlandt, 1952

Material: Baghdad, 3 exx, V-VII.1980; Shaykh Addi, 1 ex, 11.V.1981, Linnavuori.

Biology: A specimen from Turkestan in coll. Linnavuori was found on Pistacia vera.

Distribution: Possibly Anatolian, known from Cyprus and Turkestan.

Auchenocrepis alboscutellata Puton, 1874

Material: Kuwait: Al Jahra, 2 exx, 17.III.1981, Linnavuori.

Biology: On Tamarix.

Distribution: Eremian, extending from North Africa to Iran. 


\section{Auchenocrepis reuteri Jakovlev, 1878}

Material: Several exx from Amara, 23-24.X.1979; Ana, 8.X.1979; Ana-Al Qaim, 5.V.1980; Baghdad, VI-VII.1980; Hilla, 21.IX.1979; Hit, 8.X.1979; Nasiriya, 22.X.1979; Al Qaim, 10.X.1979; Samawa, 21.X.1979; Tharthar lake, 23.VI.1980, Linnavuori; Karagan near Hanekin, Djebel Hamrin, 6.VII.1931 (Hoberlandt 1949:9).

\section{Biology: On Tamarix.}

Distribution: Pontomediterranean.

\section{Tuponia (Tuponia) tamaricicola Lindberg, 1939}

Material: Ain Al Tamar, 1o probably of this species, 17.VII.1980, Linnavuori.

\section{Biology: On Tamarix.}

Distribution: Eremian, extending from North Africa to Iran.

\section{Tuponia (Tuponia) persica Wagner, 1957}

Material: Baghdad, 1 ex, IV-V.1980; Tharthar lake, 2 exx, 23.VIII.1979, Linnavuori.

\section{Biology: On Tamarix.}

Distribution: Iranian.

\section{Tuponia (Tuponia) ayasensis Wagner, 1963}

Material: Iraq: many exx from Ana-Al Qaim, 5.V.1980; Baghdad, VI-VII.1980; Nasiriya-Abu Ghar, 5.V.1980, Linnavuori. Palestine: Jericho, 2 exx, 5.V.1962, Eckerlein, in coll. Linnavuori (AMNH).

Biology: On Tamarix.

Distribution: Syrio-Anatolian, recorded from Turkey.

Tuponia (Tuponia) ninhursag Linnavuori, 1984

Types: Ana-Al Qaim, Ơ holotype, numerous paratypes, 5.V.1980, Linnavuori, in coll. Linnavuori (AMNH).

Biology: On Tamarix in a small river valley. Distribution: Endemic.

\section{Tuponia (Tuponia) ninlil Linnavuori, 1984}

Types: Nasiriya-Abu Ghar, ơ holotype, many paratypes, 15.IV.1980; Basra, 1 paratype, 12.IV.1980; Safwan, 3 paratypes, 30.III.1981, Linnavuori, in coll. Linnavuori (AMNH).

Biology: On Tamarix in salt marshes. Distribution: Endemic.

\section{Tuponia (Tuponia) carayoni vulnerata} Linnavuori, 1961

Tuponia lethierryi vulnerata Linnavuori 1961:24-25.

Tuponia vulnerata Drapolyuk 1980:54-55.

Tuponia carayoni vulnerata Linnavuori 1986:183.

Material: Many exx from Ana-Al Qaim, 5.V.1980; Baghdad, VI-VII.1980; Basra, 12.IV.1980; NajafShabakah, 1.V.1980; Rutba-Al Qaim, 4.V.1980; Tharthar lake, 2.VI.1980, Linnavuori.

Biology: On Tamarix.

Distribution: Pontomediterranean.

Tuponia (Chlorotuponia) guttata Wagner, 1950

Tuponia guttata Wagner 1950:147-149.

Tuponia variegata Wagner 1958:11 (Linnavuori 1986:186).

Material: Dawra, 6 exx, 15.IV.1979, Linnavuori.

Biology: On Tamarix.

Distribution: Eremian (Egypt - Iran).

Tuponia (Chlorotuponia) shulgi Linnavuori, 1984

Types: Baghdad, or holotype, 1 paratype, IX.1979, 1 paratype, VI-VII.1980, Linnavuori, in coll. Linnavuori (AMNH).

Biology: At lamps.

Distribution: Endemic.

Tuponia (Chlorotuponia) angusta Wagner, 1957

Material: Ana, 7 exx, 8.X.1979; Hit, 3 exx, 8.X.1979, Linnavuori.

Biology: On Tamarix.

Distribution: Iranian, previously recorded from Iran.

Tuponia (Chlorotuponia) concinna (Reuter, 1875)

Atomoscelis concinnus Reuter 1875:57.

Tuponia conspersa Reuter 1901:193 (Linnavuori 1986: 188).

Tuponia conspersa fezzana Wagner 1971:120 (Linnavuori 1986:188).

Tuponia amguela Wagner 1975b:152-153 (Linnavuori 1986:188).

Material: Numerous exx from Ain A1 Tamar, 17.VII. 1980; Amara, 23-24.X.1979; Ana-Al Qaim, 8.X.1979, 5.V.1980, 10.IV.1981; Baghdad, VI-VIII.1980; Haditha, 
13.VIII.1979; Hilla, 21.IX.1979; Hit, 8.X.1979; KarbalaAin Al Tamar, 20.X.1979; Nasiriya, 22.X.1979; Nasiriya Abu Ghar, 15.IV.1980; Wadi Mandali, 29.IX.1979, Linnavuori.

Biology: On Tamarix. In Saudi Arabia also found on Zygophyllum.

Distribution: Eremian (Algeria - Turkestan).

\section{Tuponia (Tuponia) punctipes Reuter, 1879}

Material: Numerous exx from Abu Ghuraib, 28.VI. 1977, Waiel; Ain Al Tamar, 17.VII.1980; Baghdad, IVVIII.1981; Al Hadr, 6-7.VIII.1981; Rawah-Al Hadr, 6.V. 1981; Razazah lake, 24.VI.1981, Linnavuori.

Biology: On Tamarix.

Distribution: Irano-Turanian; recorded from Iraq, Belek Sindjar (Hoberlandt 1949:9).

Tuponia (Chlorotuponia) alhagicola shamash Linnavuori, 1984

Tuponia (Chlorotuponia) shamash Linnavuori 1984:57. Tuponia (Chlorotuponia) alhagicola shamash 1986:191.

Types: Ana-Al Qaim, O' holotype and many paratypes, 9.X.1979; several paratypes from Baghdad, VIII.1980; Amara, 23-24.X.1979; Falluja, 5.X.1979; Sawa lake, 20.X.1979, Linnavuori, in coll. Linnavuori (AMNH).

Biology: On Alhagi maurorum, also found on Zygophyllum and Salsola pseudonitraria.

Distribution: Endemic, also known from Al Hasa in Saudi Arabia. The nominate form $T$. alhagicola alhagicola Drapolyuk is known from Turkestan.

\section{Tuponia (Chlorotuponia) kermanensis Wagner, 1958}

Tuponia nana Wagner 1960:134-136 (Linnavuori 1986: 191).

Material: Several exx from Amara, 23-24.X.1980; Basra, 12.IV.1980; Falluja, 5.X.1979; Karbala-Ain Al Tamar, 20.X.1979; Nasiriya-Abu Ghar, 15.IV.1980, Linnavuori.

Biology: On Salsola sp.

Distribution: Eremian, known from the Sudan, Saudi Arabia and Iran.
Tuponia (Chlorotuponia) minima Wagner, 1957

Material: Amara, 8 exx, 23-24.X.1979, Linnavuori.

Biology: On Salsola pseudonitraria.

Distribution: Eremian, extending from Egypt to Iran.

\section{Aphaenophyes richteri (Wagner, 1957)}

Material: Numerous exx from Iraq: Baghdad, VIVII.1980; Basra, 12.IV.1980; Hilla, 21.IX.1979; KarbalaAin Al Tamar, 20.X.1979; As Salman, 19.IV.1980; As Salman-Takhadid, 18.IV.1980; Wadi Mandali, 29.IX.1979; Az Zubayr, 28.II.1980, Linnavuori. Kuwait: Al Jahra, 17.III.1981, Linnavuori.

Biology: On Tamarix.

Distribution: Eremian.

\section{Camptotylus yersini (Mulsant \& Rey, 1856)}

Material: Ana, 1 ex, 8.X.1979; Dawra, several exx, 15.IX.1979; Falluja, 1 ex, 5.X.1979, Linnavuori.

Biology: On Tamarix.

Distribution: Holomediterranean.

\section{References}

Becker, A. 1864: Naturhistorische Mittheilungen. — Bull. Soc. Nat. Moscou 37(1):477-493.

Distant, W. L. 1910: The fauna of British India, including Ceylon and Burma. Rhynchota. V. Heteroptera: Appendix, pp. 228-294. Taylor \& Francis, London.

Drapolyuk, I. S. (Драполюк, И. С.) 1980: Review of Capsid bugs of the subgenus Tuponia s. str. (Heteroptera, Miridae) from the USSR and Mongolia. (In Russian) — Insects of Mongolia 7:43-68.

- 1982: Review of Capsid bugs of the subgenus Chlorotuponia (Heteroptera, Miridae) from the USSR and Mongolia. (In Russian) - Insects of Mongolia 8:148183.

Hoberlandt, L. 1949: Some Hemiptera-Heteroptera collected in North and East Iraq. - Acta Entomol. Mus. Nat. Pragae 26:1-9.

- 1953: Hemiptera-Heteroptera von Shaqlawa in Südkurdistan. - Beitr. Entomol. 3:377-384.

Kerzhner, I. М. (Кержнер, И. М.) 1984: New and little known Heteroptera from Mongolia and adjacent regions of the USSR IV. Miridae I. (In Russian) Nasekomye Mongolii 9:35-72.

Kerzhner, I. M. \& Jaczewski, T. (Кержнер, И. М. \& Яцевский, Т.) 1964: Otrjad Hemiptera (Heteroptera) - Plužestkokrylye, Ili klopi. Opredelitel nasekomyh 
europeiskoi časti SSSR I. (In Russian) - Akademija nauk SSSR. Zoologičeskii institut. pp. 655-845.

Linnavuori, R. E. 1961: Hemiptera of Israel II. - Ann. Zool. Soc. Bot. Vanamo 22(7): 1-51.

- 1971: On the genus Atomophora Rt. (Het. Miridae). - Stuttg. Beitr. Naturkunde 229:1-9.

- 1984: New species of Hemiptera Heteroptera from Iraq and the adjacent countries. - Acta Entomol. Fennica 44:1-59.

- 1986: Heteroptera of Saudi Arabia. - Fauna of Saudi Arabia 8:31-197.

- 1988: Studies on the Miridae fauna (Heteroptera) of the Middle East. - Ann. Entomol. Fennici 54:1-10.

- 1989: New species of the Miridae and Lygaeidae (Heteroptera) from the Middle East. - Ann. Entomol. Fennici 55:49-56.

- 1990: Revision of the Atomophora complex (Heteroptera, Miridae) of the Eremian subregion. - Entomol. Fennica 1:45-64.

- 1992: Hemiptera of Iraq. I. Heteroptera, Miridae (Deraeocorinae, Dicyphinae, Mirinae, and Orthotylinae). - Entomol. Fennica 3:223-231.

Poppius, B. 1914: Die Miriden der Äthiopischen Region 2. Acta Soc. Sci Fennicae 44:1-136.

Puchkov, V. G. (Пучков, В. Г.) 1975: Species of the genus Glaucopterum Wagner, 1963 (Heteroptera, Miridae) of the Soviet Union Fauna. (In Russian) Dokl. Akad. Nauk. Ukr. SSR, Ser. B. 11:1037-1042.

Reuter, O. M. 1875: Genera Cimicum Europae. — Bihang Kongl. Svenska Vetenskaps Akad. Hand1. 3:1-166.

- 1879: Hemiptera Gymnocerata Europae. Hémiptères Gymnocerates d'Europe, du bassin de la Méditerranée et de 1'Asie Russe II. - Acta Soc. Sci. Fennicae 13:193-312.

- 1890: Capsidae novae ex Africa boreali, descripsit. Revue d'Entomol. 9:255-260.

- 1901: Capsidae rossicae descriptae. - Öfv. Finska Vetenskaps Soc. Förhandl. 43:161-194.

- 1904: Capsidae novae mediterraneae V. Species a dominis J. et U. Sahlberg in itinere a. 1903-1904 collectae. - Öfv. Finska Vetenskaps Soc. Förhandl. 47(4):1-26

Schmidt, K. 1939: Beiträge zur Heteropteren-Fauna Ägyptens 2. - Bull. Soc. Fouad ler Entomol. 23:365-385.

Villiers, A. 1956: Contribution a l'étude du peuplement de la Mauretanie. Description de neouveaux Hémiptères. Bull. de l'I.F.A.N. 18(A):834-842
- 1968: A propos de la description d'Hémiptères ouestafricains. - Bull. de l'I.F.A.N. 33(A):1281-1285.

Wagner, E. 1950: Neue Hemiptera-Heteroptera aus Nordafrika. - Bull. Soc. Fouad 1 $1^{\text {er }}$ Entomol. 40:1-9.

- 1952: Einige neue Miriden Arten aus Nordafrika (Hemiptera-Heteroptera). - Bull. Soc. Fouad $1^{\text {er }}$ Entomol. 35:153-161.

- 1956a: Drei neue Miriden-Arten aus Aegypten und Bemerkungen zu einer bereits bekannten Art (Hemiptera-Heteroptera). - Bull. Soc. Entomol. Egypte 40:1-9.

- 1956b: Zur Systematik von Psallus (Apocremnus) ancorifer Fieb. 1858 (Hem. Het. Miridae). - Rev. Fac. Sci. Istanbul 21(4):199-210.

- 1958: Heteropteren aus Iran 1956. 2. HemipterenHeteropteren (Familie Miridae). — Jahresh. Ver. Naturk. Württemberg 112:74-103.

- 1960a: Zwei neue Miriden-Arten aus Saudi-Arabien. - Bull. Soc. Entomol. Egypte 44:93-96.

- 1960b: Eine neue Tuponia-Art aus Arabien (Hem. Het. Miridae). — Boll. Soc. Entomol. ItaI. 40:134 146.

- 1961a: Eine neue Maurodactylus-Art aus SaudiArabien (Hemiptera, Heteroptera: Miridae). - Bull. Soc. Entomol. Egypte 45:309-313.

- 1961b: Ein weiterer Beitrag zur Miriden-Fauna Ägyptens. - Bull. Soc. Entomol. Egypte 45:315-322.

- 1965: Die Gattung Atomoscelis Reuter 1875, und ihre Verwandten in der Palaearktis (Hem. Het. Miridae). — Notulae Entomol. 45:74-92.

- 1971: Über Tuponia Reut. (Hemiptera, Heteroptera, Miridae). - Nachrichtenbl. Bayerischen Entomologen 20:118-123.

- 1975a: Die Miridae Hahn, 1831, des Mittelmeerraumes und der Makaronesischen Inseln (Hemiptera, Heteroptera). 3. - Entomol. Abhandl. Staatl. Mus. Tierkunde Dresden 40, Suppl. 483 pp.

- 1975b: Vier neue Arten aus der Tuponia-Gruppe (Het. Miridae). —Deutsche Entomol. Zeitschr., N.F. 22:149 155.

- 1975c: Fünf neue Miriden-Arten aus Syrien (Hemiptera, Heteroptera, Miridae). - Reichenbachia 15(31): 269-277.

Received 1.XI.1992 